\title{
17. EVALUATION OF THE GEOCHEMICAL LOGGING DATA IN HOLE 959D: CÔTE D'IVOIRE-GHANA TRANSFORM MARGIN ${ }^{1}$
}

\author{
Carlos A. Gonçalves ${ }^{2}$ and Lee Ewert ${ }^{3}$
}

\begin{abstract}
Geochemical well logs were obtained in the sedimentary sequences drilled at Site 959 (Hole 959D) of the Côte D'IvoireGhana Transform Margin. Corrections have been applied to the logs to account for variations in borehole size, borehole fluid composition, downhole temperature, and logging speed and were processed to derive the concentrations of the elements Th, U, and $\mathrm{Gd}$, and the dry weight percentages of oxides in $\mathrm{Si}, \mathrm{Ca}, \mathrm{Fe}, \mathrm{Al}, \mathrm{Ti}$, and $\mathrm{K}$ at $15-\mathrm{cm}$ intervals. A geochemistry characterization of the interval logged was accomplished through statistical techniques. The log-derived geochemistry characterization shows good agreement with sedimentary changes observed during core description.
\end{abstract}

\section{INTRODUCTION}

Drilling on the Ocean Drilling Program (ODP) Leg 159 penetrated Mesozoic and Tertiary sediments on the Côte D'Ivoire-Ghana Transform Margin (Fig. 1), thereby recovering rocks of the sequence generated by this passive margin. Three sites were logged during Leg 159 , although the geochemical string was only used at Site 959 because of the bad hole conditions at the other sites (Gonçalves et al., 1995).

Geochemical logs provide continuous in situ measurements of the major rock-forming elements at $15-\mathrm{cm}$ intervals down the borehole. These provide a large database of geochemical information unaffected by several problems that inhibit core-based studies, such as incomplete or preferential core recovery and core disturbance.

This report presents the basic principles of the geochemical tool string, explains the data processing technique, and compares the processed oxide/calcium carbonate measurements estimated from the logs with sedimentary description of core measurements. A geochemistry characterization of Hole 959D was conducted by applying a non-hierarchical cluster technique to the data, and the results were compared with sedimentological classification obtained from core description.

\section{GEOCHEMICAL TOOL STRING}

The geochemical logging tool string (GLT) consists of four separate logging tools: the natural gamma-ray spectrometry tool (NGT), the compensated neutron tool (CNT), the aluminium activation clay tool (AACT), and the gamma-ray spectrometry tool (GST; Lovell et al., 1993). A schematic drawing of the GLT, which was run down Hole 959D during Leg 159, is shown in Figure 2. These four tools used three separate modes of gamma-ray spectrometry for a comprehensive elemental analysis of the formation. The NGT is located at the top of the tool string so that it can measure the naturally occurring radio nuclides, thorium $(\mathrm{Th})$, uranium $(\mathrm{U})$, and potassium $(\mathrm{K})$, before the formation is irradiated by the nuclear sources contained in the lower tools (Fig. 2). The CNT, located below the NGT, carries a Californium $\left({ }^{252} \mathrm{Cf}\right)$ neutron source to activate the $\mathrm{Al}$ atoms in the forma-

${ }^{1}$ Mascle, J., Lohmann, G.P., and Moullade, M. (Eds.), 1998. Proc. ODP, Sci. Results, 159: College Station, TX (Ocean Drilling Program).

${ }^{2}$ Laboratório de Engenharia e Exploração de Petróleo (LENEP)/UENF - Macaé/RJ, Brazil.carlos@lenep.uenf.br

${ }^{3}$ Quantscience Ltd., Melton Mowbray, Leicestershire, LE13 1AF, United Kingdom.

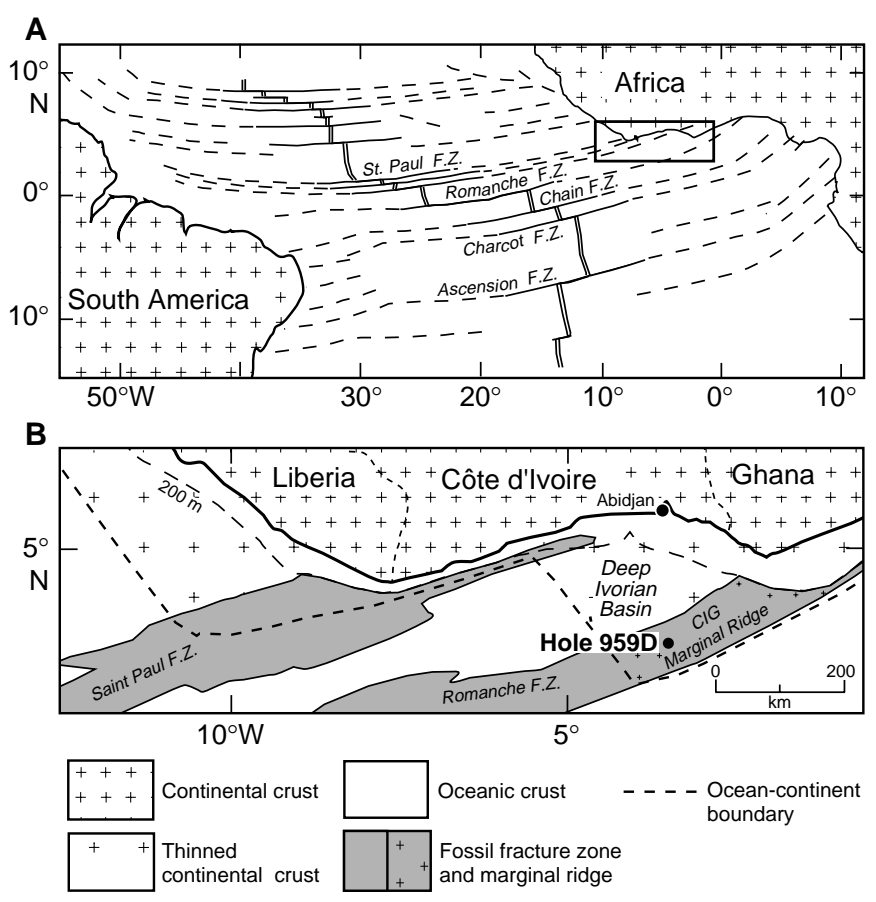

Figure 1. Location maps of Leg 159 survey area (after Mascle, Lohmann, Clift, et al., 1996).

tion. The AACT, a modified NGT, is located below the ${ }^{252} \mathrm{Cf}$ source, measuring the activated gamma-rays in the formation. Scott and Smith (1973) showed that by combining the AACT measurement with the previous NGT measurement, the background radiation can be subtracted out and a reading of the formation $\mathrm{Al}$ is obtained. The gamma-ray spectrometry tool, at the base of the string, carries a pulsed neutron generator to induce prompt-capture gamma-ray reactions in the borehole and formations and a $\mathrm{NaI}(\mathrm{Tl})$ scintillation detector to measure the energy spectrum of gamma rays generated by the prompt neutron capture reactions. As each of the elements in the formation is characterized by a unique spectral signature, it is possible to derive the contribution of each of the major elements $\mathrm{Si}, \mathrm{Fe}, \mathrm{Ca}$, $\mathrm{Ti}, \mathrm{S}, \mathrm{Gd}$, and $\mathrm{K}$ from the measured spectrum and, in turn, to estimate the relative abundance of each in the formation when combined with the elemental concentrations of the NGT and the AACT tools (Hert- 


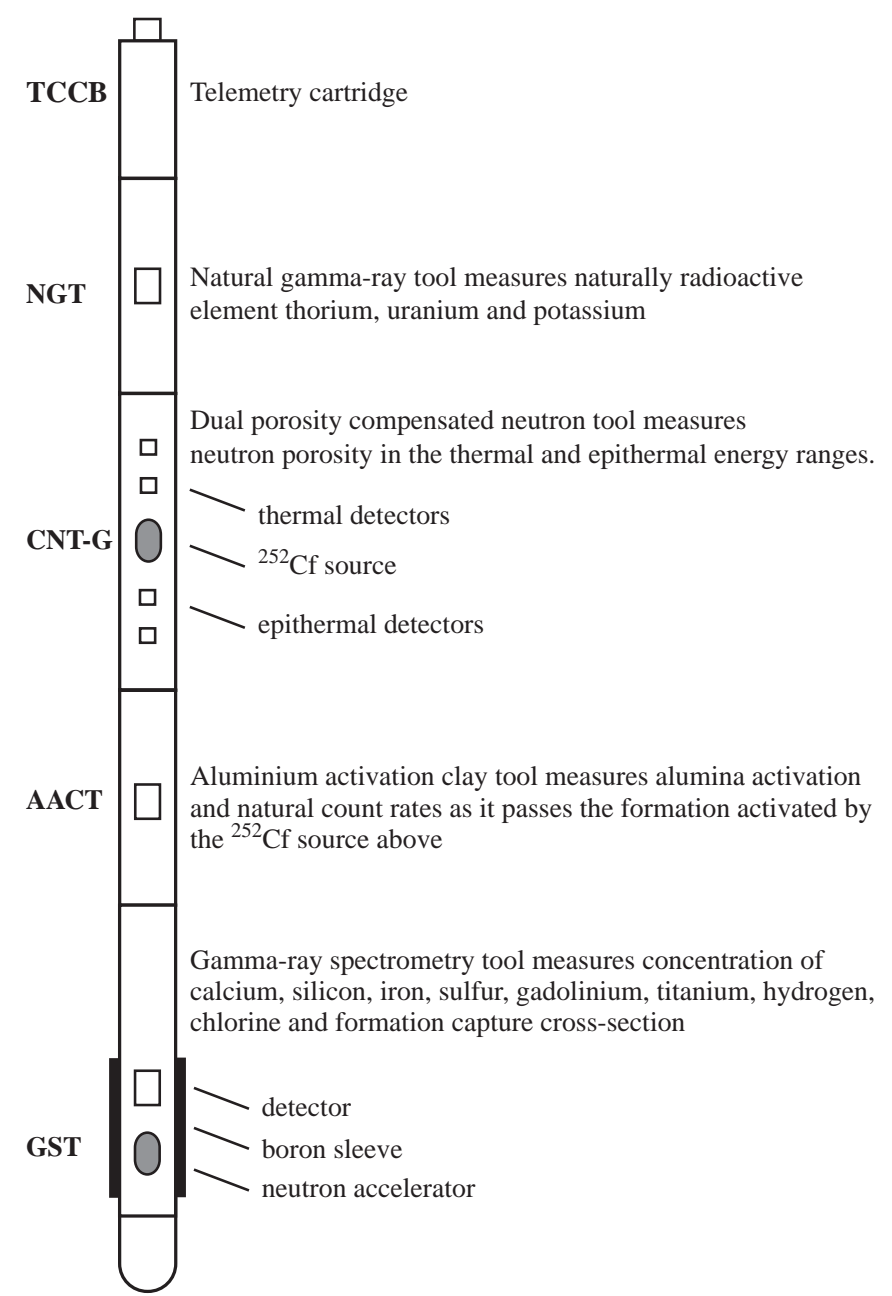

Figure 2. Schematic drawing of the Schlumberger geochemical logging tool string used in the Ocean Drilling Program.

zog et al., 1989). The GST also measures the hydrogen $(\mathrm{H})$ and chlorine $(\mathrm{Cl})$ in the borehole and the formation, although these elements are not directly used for determining the rock geochemistry.

The only major rock-forming elements not measured by the geochemical tool string are $\mathrm{Mg}$ and $\mathrm{Na}$. The neutron-capture cross sections of these elements are too small relative to their typical abundances for the GLT to detect. Hertzog et al. (1989) show that a rough estimate of $\mathrm{Mg}+\mathrm{Na}$ concentration can be obtained in some instances by using the photoelectric factor (PEF). However, there is no significance in the results when the $(\mathrm{Mg}+\mathrm{Na})$ is generally below the detection resolution of this technique (Pratson et al., 1992).

Geochemical logging data in the ODP generally show an unusually high aluminum concentration after processing. The problem might be the result of using sepiolite as a borehole fluid or even a weak Californium $\left({ }^{252} \mathrm{Cf}\right)$ source in the CNT geochemical tool. The matter is being investigated by Schlumberger.

\section{DATA ACQUISITION}

The objective of drilling at Site 959 was to recover a complete section of sediments through seismic Layers A through F (Fig. 3). These layers were defined during pre-cruise seismic surveys and are described in Mascle, Lohmann, Clift, et al. (1996). Hole 959D was drilled to 1100 meters below seafloor (mbsf). Core recovery was good in the clay of the upper $30 \mathrm{~m}$ of the hole but became just fair $(<50 \%)$ in the chert, porcellanite, black shale, sandstone, and limestone units from 30 to 500 mbsf (Mascle, Lohmann, Clift, et al., 1996). Recovery improved in the sediments between 500 and 1100 mbsf. Hole conditions prompted a decision to make a wiper trip and ream the hole. During the wiper trip, however, swelling clay bridges prevented the bottom-hole assembly (BHA) from passing below 900 mbsf. The hole was then conditioned with a K-based mud to stabilize the clay. For each logging run the pipe was set to $300 \mathrm{mbsf}$. Three logging passes were completed in Hole 959D. The first logging run was done with the quad combo tool string, which consisted of the array sonic tool, the lithodensity tool, the natural gamma-ray tool, the phasor dual-induction resistivity tool, and the Lamont-Doherty temperature tool. Two passes were made with this string. The second run was made with the Formation MicroScanner (FMS) logging tool string, and the third with the geochemical tool string. Despite bad hole conditions (enlargement of the hole diameter) in some sections, good quality data were obtained for most of the interval.

\section{DATA REDUCTION}

The geochemical well-log data of Schlumberger tools are transmitted digitally up a wireline and are recorded and processed on the JOIDES Resolution in the Schlumberger Cyber Service Unit (CSU). The results from the CSU are made available as "field logs" for initial shipboard interpretation. Subsequent reprocessing is necessary to correct the data for the effects of fluids added to the well, logging speed, and drill-pipe interference. Processing of the spectrometry data is required to transform the relative elemental yields into oxide weight fractions. The processing is performed with a set of log-interpretation programs written by Schlumberger but have been slightly modified to account for the lithologies and hole conditions encountered in ODP holes (Bristow and DeMenocal, 1992). The processing flow is summarized in Figure 4, and all the different processing steps for the geochemical data during Leg 159 are described below.

\section{Reconstruction of Relative Elemental Yields from Recorded Spectral Data}

The first processing step compares the measured spectra from the gamma-ray spectrometry tool with a series of standard spectra to determine the relative contribution or yield of each element. These standards approximate the spectrum of each element. Using a weighted, least-square inversion method, the relative elemental yields are calculated at each depth level.

Six elemental standards, including $\mathrm{Si}, \mathrm{Fe}, \mathrm{Ca}, \mathrm{S}, \mathrm{Cl}$, and $\mathrm{H}$, are used to produce the shipboard yields, but three additional standards ( $\mathrm{Ti}, \mathrm{Gd}$, and $\mathrm{K}$ ) can be included in the postcruise processing to improve the fit of the spectral standards to the measured spectra (Grau et al., 1990; Pratson et al., 1992). The ability to detect an element is principally dependent on the size of its captured cross section and its abundance in the formation. Although Ti, Gd, and $\mathrm{K}$ often appear in the formation in very low concentrations, they can make a significant contribution to the measured spectra because they have large neutron-captured cross sections. Hertzog et al. (1989) have shown that Gd for example, has a capture cross section of 49,000 barns, whereas that of $\mathrm{Si}$ is 0.16 barns. Therefore, including Gd is necessary when calculating the best fit of the standard spectra to the measured spectrum, even though its typical concentration is only a few parts per million.

The eight elemental standards ( $\mathrm{Si}, \mathrm{Ca}, \mathrm{Fe}, \mathrm{Ti}, \mathrm{Gd}, \mathrm{S}, \mathrm{Cl}$, and $\mathrm{H}$ ) were used in the spectral analysis step for Hole 959D. The spectral standard for $\mathrm{K}$ was not used in the final analysis because its inclusion in the spectral inversion was found to increase the noise level in the 
Marginal Ridge

Hole 959

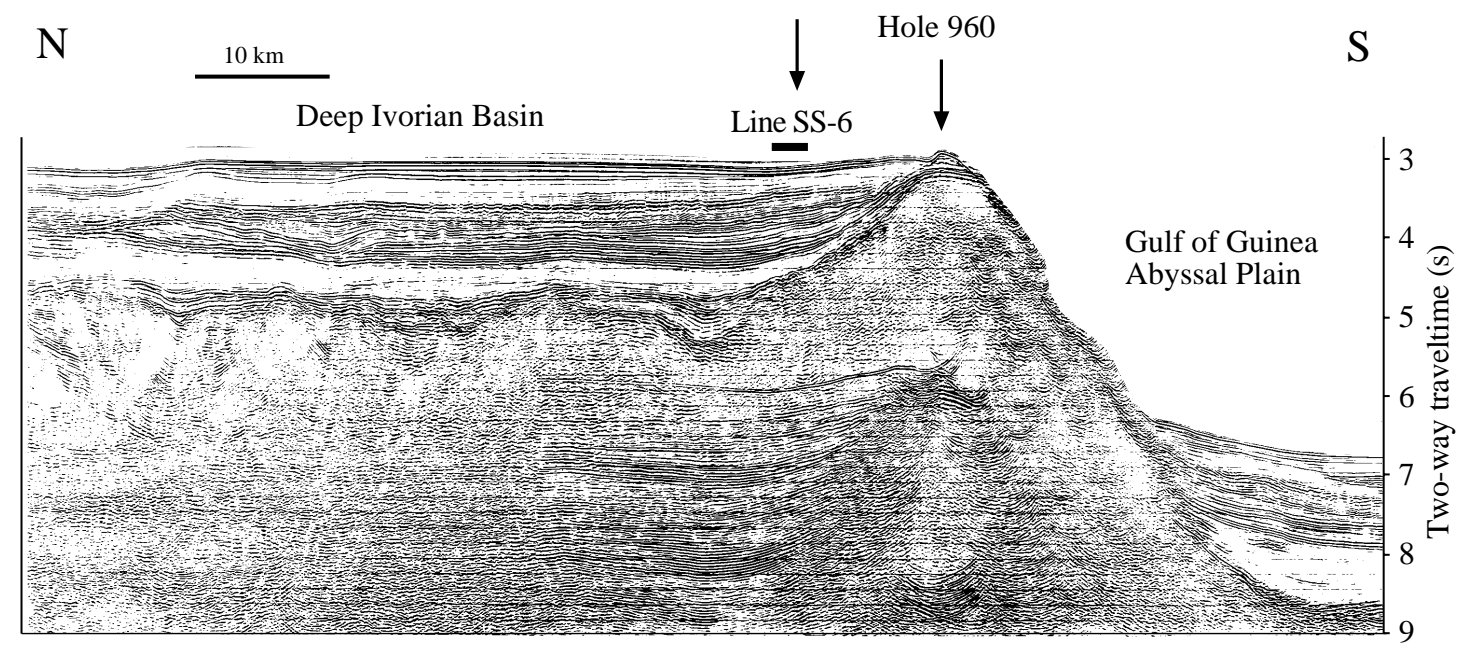

\section{Line SS-6}

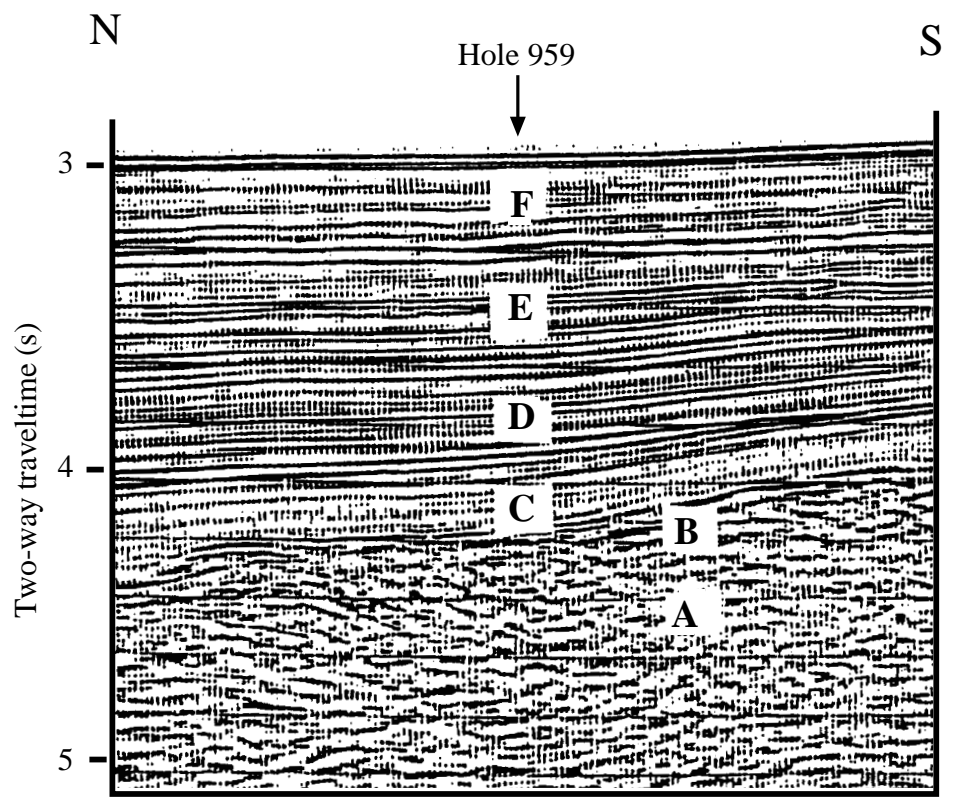

Figure 3. Seismic lines across Sites 959 and 960 at the top and across Site 959 (detailed) at the bottom (after Mascle, Lohmann, Clift, et al., 1996).

other elemental yields. A linear 10 points $(1.52 \mathrm{~m})$ moving average was applied to the output elemental yields to increase the signal-tonoise ratios.

\section{Depth Shifting}

Geochemical processing involves the integration of data from different tool strings; consequently, it is important that all the data are depth shifted to one reference logging run. The NGT tool, run in each of the logging tool strings, provides a spectral gamma-ray curve with which to correlate each of the logging runs. A reference run is chosen on the bases of both constant and low cable tension and high cable speed (tools running at faster speeds are less likely to stick and are less susceptible to data degradation caused by ship heave). The depth-shifting procedure involves picking a number of reference points based on similar log characteristics and then invoking a program which expands and compresses the matching logging run to fit the reference logging run. The main run of the Quad combination tool string was used as a reference run for Hole 959D mainly because it was run at a faster speed- $900 \mathrm{ft} / \mathrm{hr}$.

\section{Calculation of Total Radioactive and Th, U, and $\mathrm{K}$ Concentrations}

The third processing step calculates the total natural gamma-ray radiation in the formation, as well as concentrations of Th, $\mathrm{U}$, and $\mathrm{K}$, using the counts in five of spectral windows from the NGT (Lock and Hoyer, 1971). This routine resembles shipboard processing; however, the results are improved during postcruise processing by including corrections for hole size changes and variations in temperature. A 
Figure 4. Flow diagram summarizing the postcruise processing of the geochemical logging data. Processing routine names are in bold italics (after Bristow et al., 1992).

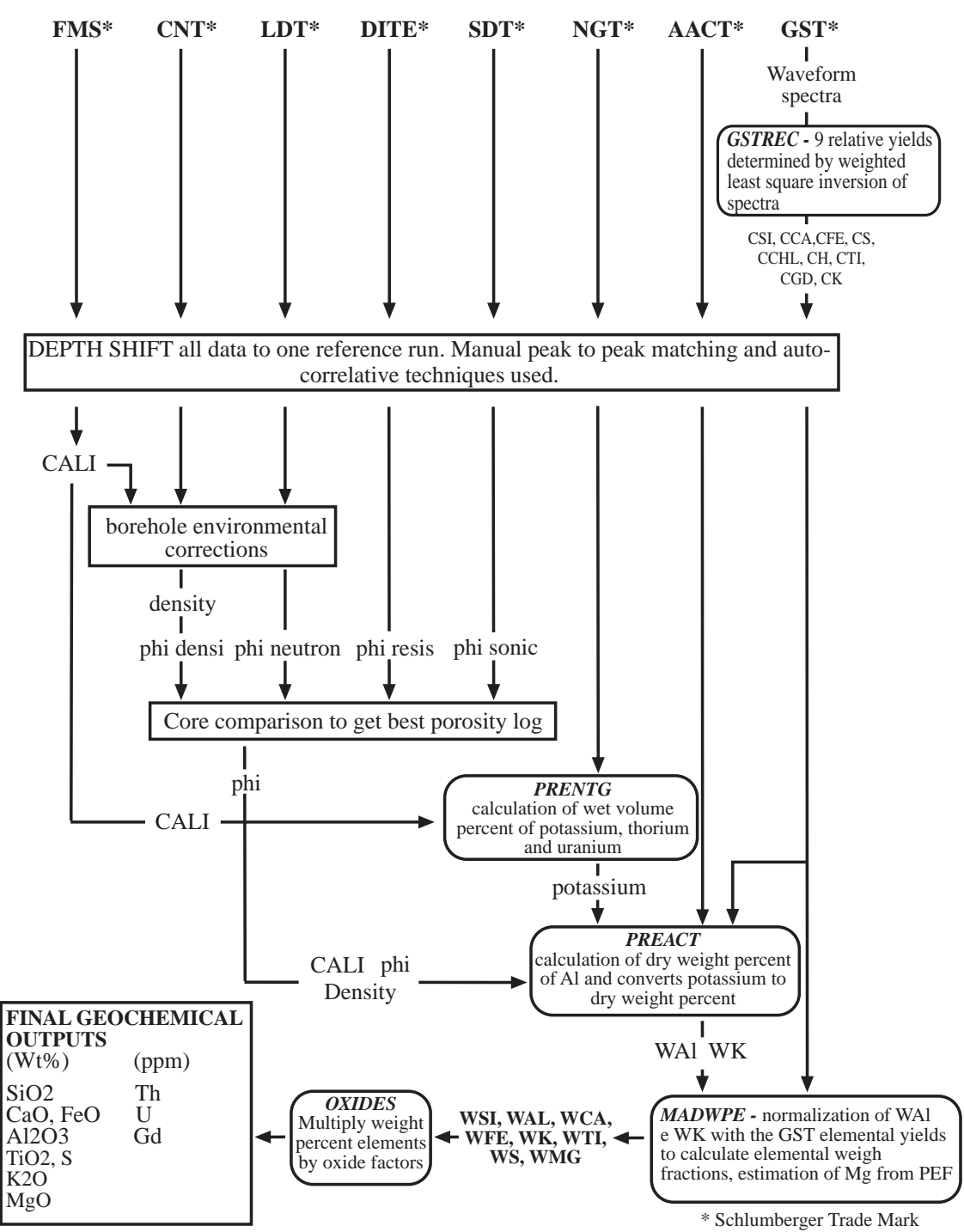

Kalman filtering system (Ruckebusch, 1983) is used in the CSU processing at sea to minimize the statistical uncertainties in the logs, which can otherwise create erroneous negative values and anti-correlation, especially between Th and U. An alpha filter has been introduced more recently and is now recommended by Schlumberger for shore-based processing. This filter strongly smoothes the raw spectral counts but keeps the total gamma-ray curve unsmoothed before calculating out the Th, $\mathrm{U}$, and $\mathrm{K}$. The outputs of this program are $\mathrm{K}$ (wet wt\%), U (ppm) and Th (ppm), as well as total gamma-ray and computed gamma ray (total gamma ray minus $U$ contribution). They are displayed as a function of depth in the log summary figures at the end of the "Site 959" chapter in Mascle, Lohmann, Clift, et al. (1996).

\section{Calculation of Al Concentration}

The fourth processing routine (PREACT) calculates the concentration of $\mathrm{Al}$ in the formation using recorded gamma-ray data from four energy windows on the AACT. During this step, corrections are made for natural radioactivity, borehole-fluid neutron-capture cross section, formation neutron-capture cross section, formation slowingdown length, and borehole size.

Porosity and density logs are needed as inputs into this routine to convert the wet weight percentages of $\mathrm{K}$ and $\mathrm{Al}$ curves to dry weight percentages. To derive the best porosity log, shipboard core porosity measurements were compared with porosity logs calculated from the resistivity (Archie, 1942) and bulk density logs, and taken from the neutron porosity tool. The best porosity log was derived by a splice of the resistivity porosity (530-744 mbsf) and the neutron porosity (744-930 mbsf). The bulk density log used as input into PREACT was edited to remove extremely low values caused by borehole washouts over the intervals 769-809 and 867-873 mbsf.

A correction is also made for $\mathrm{Si}$ interference with $\mathrm{Al}$; the ${ }^{252} \mathrm{Cf}$ source activates the $\mathrm{Si}$, producing the $\mathrm{Al}$ isotope, ${ }^{28} \mathrm{Al}$ (Hertzog et al., 1989). The program uses the Si yield from the GST to determine the Si background correction. The program outputs dry weight percentages of $\mathrm{Al}$ and $\mathrm{K}$, which are combined in the next processing step with the GST-derived elemental yields in the oxide closure model.

\section{Normalization of Elemental Yields from the GST to Calculate the Elemental Weight Fractions}

Relative concentrations of the GST-derived elemental yields can be determined by dividing each elemental yield by a relative spectral sensitivity factor $\left(S_{i}\right)$. This factor is principally related to the thermal neutron-capture cross sections and also to its gamma-ray production and the detection probability of each element (Hertzog et al., 1989). 
The relative elemental concentrations are related to the desired absolute concentrations by a depth-dependent normalization factor $(\mathrm{F})$, as defined by the relationship:

$$
W t_{i}=\mathrm{F} Y_{i} / S_{i}
$$

where $W t_{i}$ is the absolute elemental concentration and $Y_{i}$ is the relative elemental yield.

The normalization factor is calculated on the basis that the sum of all the elemental weight fractions is unity $(100 \%)$. The closure model handles the absence of carbon and oxygen, which are not measured by the geochemical tool or by any other tool in the same tool string, and approximates that each of the measurable elements combines with a known oxide or carbonate. The dry weight percent of $\mathrm{Al}$ and $\mathrm{K}$ are normalized with the reconstructed elemental yields to determine the normalization factor at each depth interval from the following equation:

$$
\mathrm{F}\left(\sum_{i} X_{i} Y_{i} / S_{i}\right)+X_{k} W t_{k}+X_{A l} W t_{A l}=1
$$

where $X_{i}$ is the oxide factor, atomic weight of the associated oxide or carbonate of element $i$ divided by the atomic weight of element $i ; X_{k}$ is the oxide factor, atomic weight of $\mathrm{K}_{2} \mathrm{O}$ divided by the atomic weight of $\mathrm{K}$; $W t_{k}$ is the dry-weight percentage of $\mathrm{K}$ determined by the NGT; $X_{A l}$ is the oxide factor, atomic weight of $\mathrm{Al}_{2} \mathrm{O}_{3}$ divided by the atomic weight of $\mathrm{Al}$; and $W t_{A l}$ is the dry weight percentage of $\mathrm{Al}$, as determined from the AACT.

The value $X_{i}$, accounts for the $\mathrm{C}$ and $\mathrm{O}$ associated with each element. Table 1 lists the oxide factors used in this calculation for Hole 959D.

\section{Calculation of Oxide Percentages}

This routine converts the elemental weight percentages into oxide percentages by multiplying each element by its associated oxide factor as shown in Table 1. The results are displayed as a function of depth later in this paper.

\section{Calculation of Error Logs}

The statistical uncertainty of each element is calculated for each of the elements measured with the GST and the NGT (Grau et al., 1990; Schweitzer et al., 1988). This error is strongly related to the normalization factor, which is calculated at each depth level. The normalization factor is generally displayed to the right of the oxide logs. A lower normalization factor represents better counting statistics and therefore higher quality data.

Table 1. Oxide factors used in normalizing elements to $100 \%$ and converting elements to oxides.

\begin{tabular}{clc}
\hline Element & $\begin{array}{c}\text { Oxide/ } \\
\text { Carbonate }\end{array}$ & $\begin{array}{c}\text { Conversion } \\
\text { factor }\end{array}$ \\
\hline $\mathrm{Si}$ & $\mathrm{SiO}_{2}$ & 2.139 \\
$\mathrm{Ca}$ & $\mathrm{CaCO}_{3}$ & 2.497 \\
$\mathrm{Fe}$ & $\mathrm{FeO}^{*}$ & 1.358 \\
$\mathrm{~K}$ & $\mathrm{~K}_{2} \mathrm{O}$ & 1.205 \\
$\mathrm{Ti}$ & $\mathrm{TiO}_{2}$ & 1.668 \\
$\mathrm{Al}$ & $\mathrm{Al}_{2} \mathrm{O}_{3}$ & 1.889 \\
\hline
\end{tabular}

Note: $\mathrm{FeO} *=\mathrm{FeO}+\mathrm{Fe}_{2} \mathrm{O}_{3}$.

\section{RESULTS: DATA QUALITY AND FORMATION CHARACTERIZATION USING GEOCHEMISTRY DATA}

An initial appraisal of the quality of the geochemical logging data can be made by looking at some statistics and internal relationships of the data set. This gives an indication of the integrity of the data set as a function of depth. Figure 5 shows the average weight percentages of log-derived elemental oxides for the whole interval logged in Hole 959D. These data are also listed in Table 2 where the data set have been normalized. The variance of some oxides is insignificantly high. Unfortunately, by the time of this analysis, no XRF data were available for comparison. A few $\mathrm{CaCO}_{3}$ measurements were performed on board, and their mean is also shown in Figure 5. There is very good agreement, although the variance of the $\mathrm{CaCO}_{3} \log$ is greater. As a function of depth, the few $\mathrm{CaCO}_{3}$ core measurements available were plotted together with log-derived $\mathrm{CaCO}_{3}$ (Fig. 6). Again, a reasonable agreement is observed.

A more complete statistical characterization can be made through a Hierarchical Cluster Analysis. This technique operates in a similarity matrix, which may be based on a variety of measurements. The most commonly used is distance (e.g., the distance between the nearest element in each cluster or the distance between the centroids of each cluster, or even measurements based on correlation). If standardized data are used, which is the case of this work, measurements of distance and correlation coefficients may be directly transformed from one to another. Similarly, distance may be looked on as a measure of dissimilarity.

Davis (1986) shows that, in general, distance-based measures tend to cluster more successfully using cophenetic correlation than

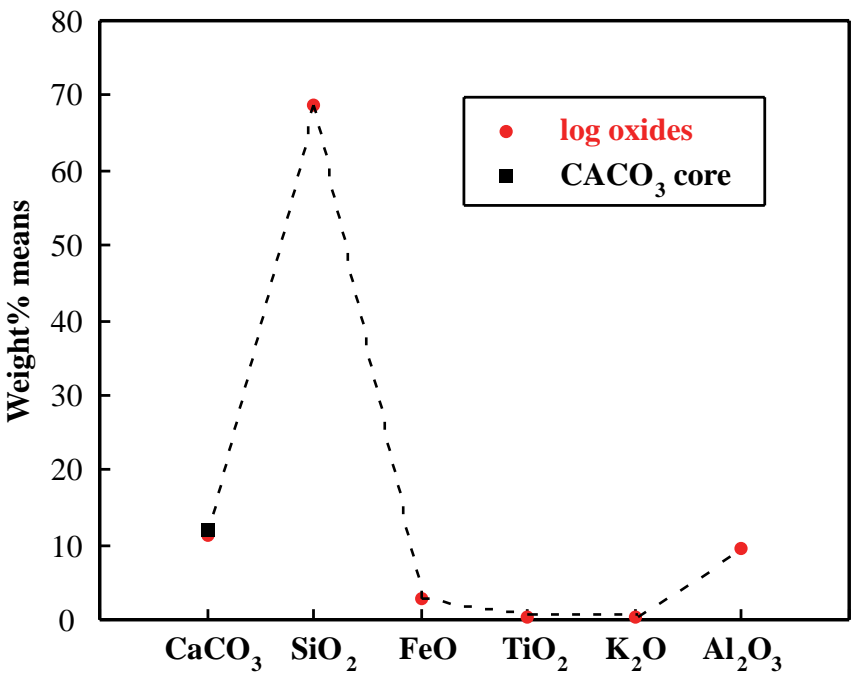

Figure 5. Arithmetic means of $\log$ oxide data for Hole 959D. $\mathrm{CaCO}_{3}$ core measurements are also plotted for comparison.

Table 2. Summary statistics for geochemical log-derived oxides for Hole 959D.

\begin{tabular}{lcccccc}
\hline & $\mathrm{CaCO}_{3}$ & $\mathrm{SiO}_{2}$ & $\mathrm{FeO}^{*}$ & $\mathrm{TiO}_{2}$ & $\mathrm{~K}_{2} \mathrm{O}$ & $\mathrm{Al}_{2} \mathrm{O}_{3}$ \\
\hline $\begin{array}{l}\text { Mean } \\
\begin{array}{c}\text { Standard } \\
\text { deviation }\end{array}\end{array}$ & 9.9057 & 1172.513 & 1.3143 & 0.30714 & 0.25853 & 5.2002 \\
\begin{tabular}{c} 
Variance \\
\hline
\end{tabular} & 98.124 & 110.52 & 1.7275 & 0.09433 & 0.06683 & 27.042 \\
\hline
\end{tabular}

Note: $\mathrm{FeO} *=\mathrm{FeO}+\mathrm{Fe}_{2} \mathrm{O}_{3}$. 

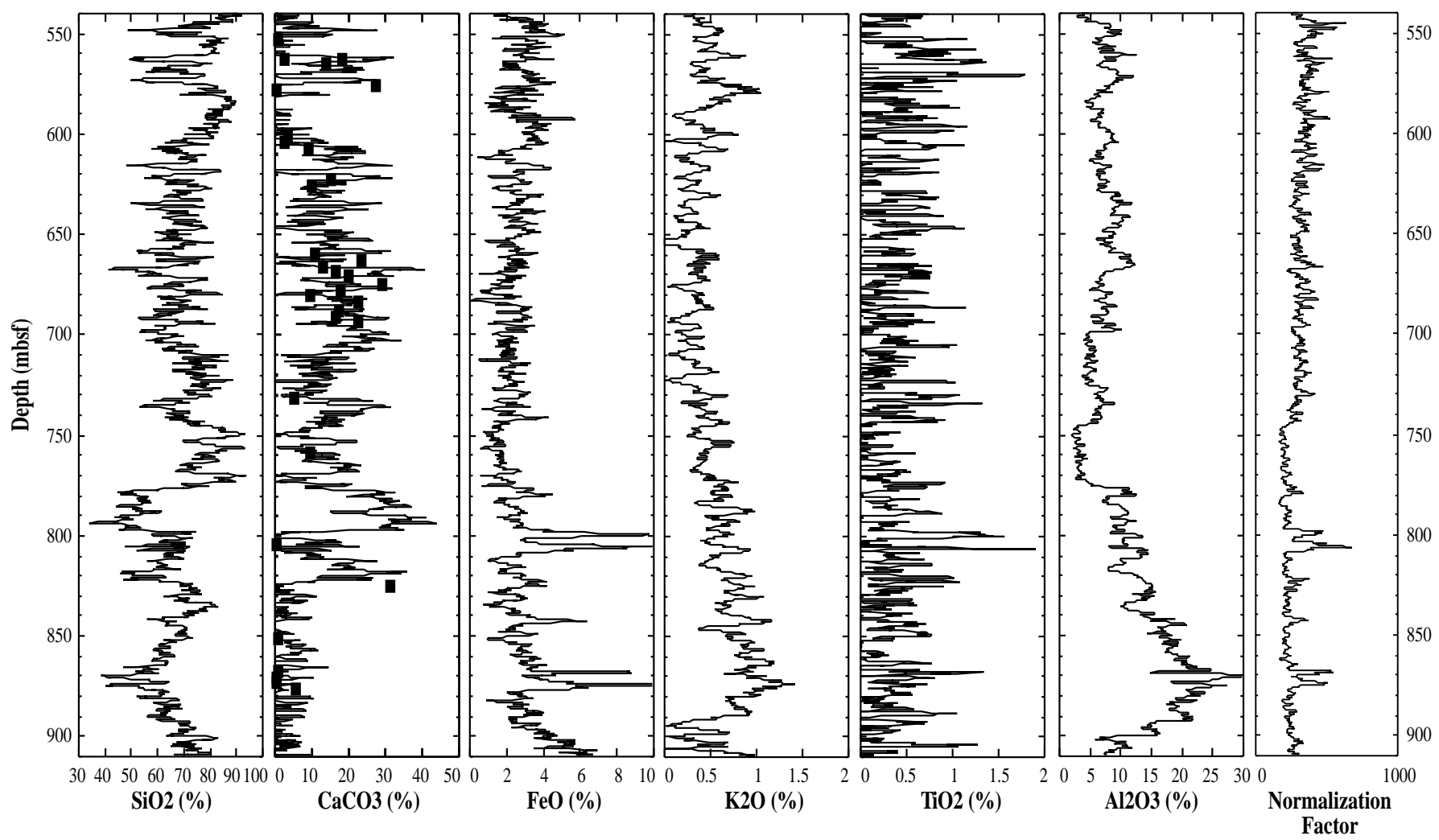

Figure 6. Geochemical logs and normalization factor for Hole 959D.

correlation-based measures. They also appear to be less susceptible to changes in clustering method. Although the two measurements tend to give similar results, the distance-based methods are not constrained between \pm 1.0 and, therefore, may be expected to produce better results if a few of the data units are very dissimilar from one to another. The results here are shown as a dendogram (Fig. 7). Gonçalves (1995) explains, in more detail, the alternative approaches of this technique.

A serious problem with the hierarchical procedures is that their theoretical basis is still incomplete. The statistical properties of the various techniques are poorly understood and there are few tests of significance. Therefore, there is not the same need as with the other multivariate statistical techniques for a multivariate normal distribution. Multivariate normality does, however, become important if correlations are taken as the measure of similarity.

The algorithm used in clustering can be viewed in three stages. The first stage is the input of the log data. The second stage is the computation of a similarity/dissimilarity matrix. The third stage is the clustering of the similarity/dissimilarity matrix using one of a selection of models presented below.

The similarity/dissimilarity matrix supports

1. A product moment correlation matrix (similarity),

2. A Euclidean distance — not normalized matrix (dissimilarity), or

3. A Euclidean distance-Z-standardized (dissimilarity).

The clustering algorithms can be computed from the following models:

1. Nearest neighbors, which uses a single linkage and minimum method;
Group Averages Model

Cophenetic Correlation: 0.934

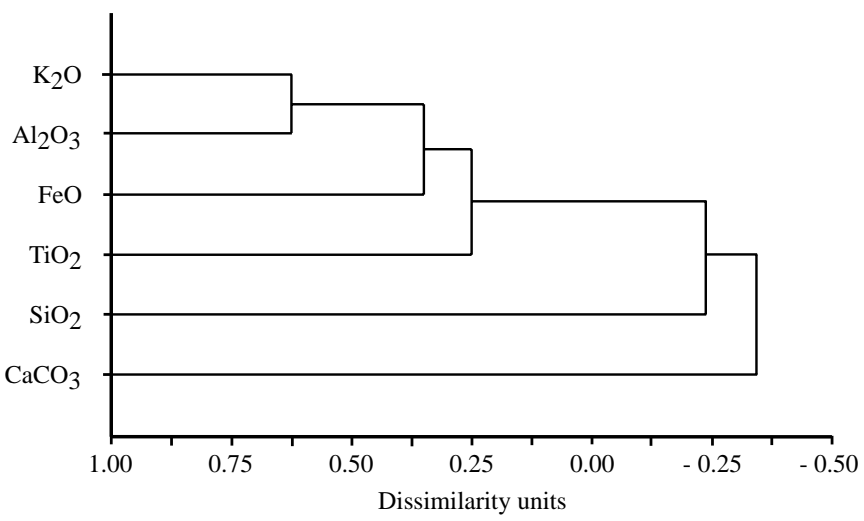

Figure 7. Dendogram showing the correlation between the log oxides in Hole 959D.

2. Further neighbors, which uses complete linkage and maximum method;

3. Simple averages, the weighted pair-group method;

4. Median, the weighted pair group centroid;

5. Group averages, the unweighted pair-group method;

6 . Centroid, the weighted pair-group centroid; and

7. Wards method, which uses the minimum group variance.

Because the log data are normalized before processing, the hierarchical clustering is conducted using the Euclidean distance Z-standardized similarity/dissimilarity matrix. After running the algorithm for 
Table 3. Hierarchical cluster analysis (product moment correlation matrix) for Hole 959D.

\begin{tabular}{lcccccc}
\hline \multicolumn{7}{c}{ Product moment correlation matrix } \\
\hline $\mathrm{CaCO}_{3}$ & $\mathrm{SiO}_{2}$ & $\mathrm{FeO}$ & $\mathrm{TiO}_{2}$ & $\mathrm{~K}_{2} \mathrm{O}$ & $\mathrm{Al}_{2} \mathrm{O}_{3}$ \\
$\mathrm{CaCO}_{3}$ & 1.0000 & -0.6405 & -0.2437 & -0.2146 & -0.2829 & -0.3246 \\
$\mathrm{SiO}_{2}$ & - & 1.0000 & -0.2573 & 0.0505 & -0.2677 & -0.4790 \\
$\mathrm{FeO}^{2}$ & - & - & 1.0000 & 0.2533 & 0.3591 & 0.3492 \\
$\mathrm{TiO}_{2}$ & - & - & - & 1.0000 & 0.0851 & 0.0532 \\
$\mathrm{~K}_{2} \mathrm{O}$ & - & - & - & & 1.0000 & 0.6352 \\
$\mathrm{Al}_{2} \mathrm{O}_{3}$ & - & - & - & - & - & 1.0000 \\
\hline
\end{tabular}

Table 4. Hierarchical cluster analysis (cophenetic correlation coefficient for each linkage method) for Hole 959D.

\begin{tabular}{ccl}
\hline Model & $\begin{array}{c}\text { Cophenetic } \\
\text { correlation }\end{array}$ & \multicolumn{1}{c}{$\begin{array}{c}\text { Linkage } \\
\text { method }\end{array}$} \\
\hline 1 & 0.8677 & Nearest neighbors \\
2 & 0.9055 & Furthest neighbors \\
3 & 0.8923 & Simple averages \\
4 & 0.8074 & Median \\
5 & 0.9345 & Group averages \\
6 & 0.8667 & Centroid \\
7 & 0.8226 & Wards method \\
\hline
\end{tabular}

Table 5. Hierarchical cluster analysis (results for the group average model) for Hole 959D.

\begin{tabular}{cccccc}
\hline \multicolumn{2}{c}{ Model 5: group averages } & & \multicolumn{3}{c}{ Cophenetic correlation: 0.934 } \\
\cline { 1 - 3 } \cline { 4 - 5 } \cline { 4 - 5 } Link no. & Variable retained & & Variable deleted & Similarity level & Linkage order \\
1 & 5 & & 6 & 0.6352 & 1 \\
2 & 3 & & 5 & 0.3541 & 2 \\
3 & 3 & & 4 & 0.1306 & 3 \\
4 & 2 & & -0.2384 & 5 \\
5 & 1 & & -0.3413 & 6 \\
& & & & & 4 \\
\hline
\end{tabular}

some of the linkage models listed above, a model with the highest cophenetic correlation is selected for a full analysis.

The results from the Hierarchical Cluster Analysis for Hole 959D are shown in Tables 3 through 5. Tables 3 through 5 present the Euclidean distance matrix, the results for some of the linkage methods, and the detailed result for the method which presents the best cophenetic correlation. The cophenetic correlation, which represents the degree of distortion in the dendogram, are greater than 0.8 for most of the linkage methods presented. Shepherd (1986) shows that 0.8 is an acceptable value for cophenetic correlation. The group averages method (model 5, above), shows the best cophenetic correlation value, greater than 0.93 , and was used for the analysis, the results of which are detailed in Table 3.

The dendogram (Fig. 7) shows the relationships between the log curves used in this analysis. It shows strong correlation between $\mathrm{Al}_{2} \mathrm{O}_{3}$ and $\mathrm{K}_{2} \mathrm{O}$, with approximately 0.63 units of dissimilarity. $\mathrm{FeO}$, $\mathrm{TiO}_{2}, \mathrm{SiO}_{2}$, and $\mathrm{CaCO}_{3}$ also appear connected to the main correlating pair $\mathrm{Al}_{2} \mathrm{O}_{3}$ and $\mathrm{K}_{2} \mathrm{O}$ at $0.35,0.25,-0.23$ and -0.34 levels of dissimilarity, respectively. The strong correlation between $\mathrm{K}_{2} \mathrm{O}$ and $\mathrm{Al}_{2} \mathrm{O}_{3}$ is probably related to the amount of clay at the black claystone unit observed from $812 \mathrm{mbsf}$ downhole. $\mathrm{CaCO}_{3}$ and $\mathrm{SiO}_{2}$ appear as the highest levels of dissimilarity related mostly to the presence of Opal and nannofossil chalk in the upper part of the interval logged.

This result obtained with the dendogram (Fig. 7) is confirmed when a non-hierarchical cluster technique is applied to the data. The classification technique employed here characterizes the geochemical log responses and helps to define any geochemical zonation that might be identified from the data set. The non-hierarchical cluster is a simple method, available for a number of years under one name or another (for instance, $\mathrm{K}$ = clustering and relocation analysis; see Le Maitre, 1982; Johnson and Wichern, 1982; Shepherd, 1986). The objective of the technique is to classify (or split) a multivariate data set into groups of samples (log responses) that have similar characteristics.

In this work, we use the nearest (Euclidean) centroid as the basis of classification rule. One of the major problems is the selection of the number of groups. This selection seems to be obvious in a two dimensional space; however, it is not so simple in a real multidimensional situation, where there is no prior knowledge of the data.

In addition to group membership for each log response, this analysis yields a computation of the "delta values" $(\delta)$, which rate the importance of each log curve in terms of group discrimination. "Delta values" provide a measure of the separating power of individual log curve for the various combinations of groups. They allow the importance of each log curve in group discrimination to be assessed. From the values of $\delta$ obtained for each log curve in each combination of groups, three parameters are estimated. The first one is an overall least to most important log curve. This is achieved by calculating the mean of the $\delta$ values for each log curve and then sorting then into ascending order. The second parameter is the identification of the worst to best $\log$ curves of each group combination. Therefore, it allows the analyst to assess the log curves which have more weight in the lithofacies discrimination. The $\delta$ values of each log curve are comparable, as they have all been standardized against standard deviation. The last parameter refers to the overall ease of distinguishing various group combinations. The mean of all $\delta$ values for each combination are calculated and then assorted into ascending order. Gonçalves (1995) gives a detailed explanation on how the "delta values" are obtained.

Initial testing for the number of groups present in the data set resulted in three main groups being selected as the optimum number for the full analysis (Fig. 8). Group 1, defined between 540 and 770 mbsf, is related to low values of $\mathrm{Al}_{2} \mathrm{O}_{3}$ and $\mathrm{CaCO}_{3}$. Group 2 appears as several thin layers (between 1 and $8 \mathrm{~m}$ thick) above $770 \mathrm{mbsf}$ interbedded by group 1, and as a consistent unit between 770 and 820 mbsf. It is characterized by high $\mathrm{CaCO}_{3}$ values (and consequently low to moderate $\mathrm{SiO}_{2}$ ) and a small increase in $\mathrm{Al}_{2} \mathrm{O}_{3}$. Group 3 is strongly represented from $820 \mathrm{mbsf}$ downhole, where it appears to be sometimes interbedded by group 1 . Very low $\mathrm{CaCO}_{3}$ values and high $\mathrm{Al}_{2} \mathrm{O}_{3}$ values are characteristics of this unit. According to the sedimentary classification proposed by the Scientific Party, group 1 would represent the porcellanite or Subunit IIC (Mascle, Lohmann, Clift, et al., 1996). Clay-rich lithologies at the top of the interval characterizes group 3, with increases in $\mathrm{Al}_{2} \mathrm{O}_{3}$. The interbedded layers of group 2 are revealed by the increase of micrite in the formation and consequently and increase in $\mathrm{CaCO}_{3}$. Particularly important in Unit IIC is the increase in $\mathrm{SiO}_{2}$ at intervals related with the development of Opal formed from the diagenetic alteration of siliceous microfossils. The increase in carbonate content downhole causes gradational changing from porcellanite with clay to porcellanite with micrite, and subsequently to porcellanite nannofossil chalk across the boundary between Subunit IIC and Unit III at 812 mbsf. Unit III is defined from 812 mbsf downhole as a black claystone and claystone with nannofossil. The upper $20 \mathrm{~m}$ consisted of claystone, nannofossil claystone, and micrite claystone, which contains interbedded groups 2 and 3 in the geochemical classification depending on the $\mathrm{CaCO}_{3}$ content. From 840 mbsf the increase in claystone and black claystone is defined by a dominance of group 3 in the statistical classification with a subsequent increase in $\mathrm{Al}_{2} \mathrm{O}_{3}, \mathrm{FeO}$, and $\mathrm{K}_{2} \mathrm{O}$ because of clay abundance.

In terms of group discrimination, $\mathrm{Al}_{2} \mathrm{O}_{3}$ and $\mathrm{CaCO}_{3}$ were rated the three most important log curves in the analysis based on their averages delta values (Table 4). The most important log curves for the discrimination between each group are also show in Table 4 . In the sep- 


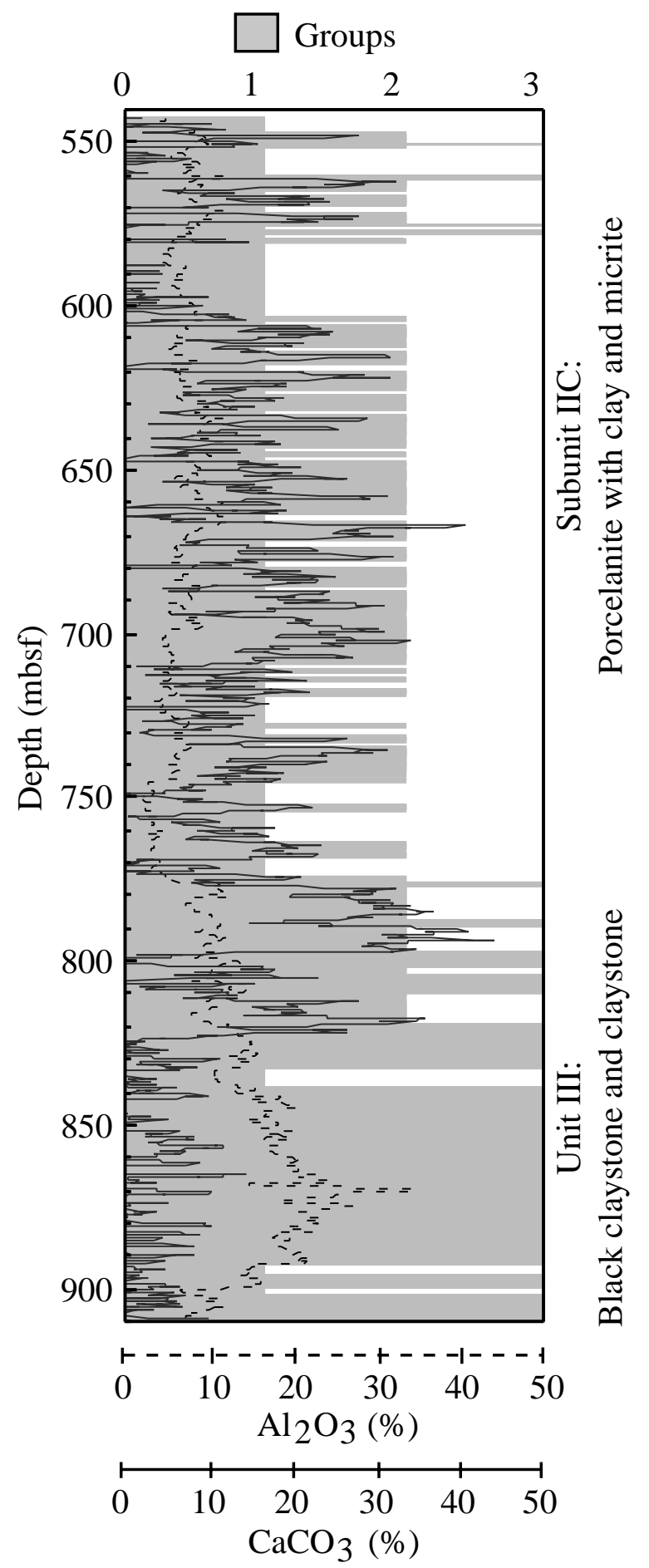

Figure 8. Lithologic characterization using log-derived oxides. $\mathrm{Al}_{2} \mathrm{O}_{3}$ and $\mathrm{CaCO}_{3}$ oxides are also plotted for comparison.
Table 6. Importance of $\log$ curves in group discrimination and the hardest and simplest combination to distinguish in Hole 959D.

\begin{tabular}{|c|c|c|c|c|}
\hline \multicolumn{5}{|c|}{ Summary of delta values } \\
\hline $\begin{array}{l}\mathrm{TiO}_{2} \\
\mathrm{FeO} \\
\mathrm{K}_{2} \mathrm{O} \\
\mathrm{SiO}_{2} \\
\mathrm{Al}_{2} \mathrm{O}_{3} \\
\mathrm{FeO} \\
\mathrm{K}_{2} \mathrm{O} \\
\mathrm{TiO}_{2} \\
\mathrm{Al}_{2} \mathrm{O}_{3} \\
\mathrm{CaCO}_{3}\end{array}$ & $\begin{array}{l}\text { Over } \\
\text { Wor }\end{array}$ & $\begin{array}{l}\text { lost important element } \\
\text { ment for clusters } 1 \text { and } 2\end{array}$ & $\begin{array}{l}0.30\{\mathrm{M} \\
0.69 \\
1.48 \\
1.78 \\
2.23\{\mathrm{Me} \\
0.03\{\mathrm{De} \\
0.04 \\
0.36 \\
0.37 \\
2.76\{\mathrm{De}\end{array}$ & $\begin{array}{l}\text { an of delta values\} } \\
\text { an of delta values }\} \\
\text { ta } \\
\text { ta }\end{array}$ \\
\hline $\begin{array}{l}\mathrm{TiO}_{2} \\
\mathrm{CaCO} \\
\mathrm{FeO} \\
\mathrm{SiO}_{2} \\
\mathrm{~K}_{2} \mathrm{O} \\
\mathrm{Al}_{2} \mathrm{O}_{3}\end{array}$ & \multicolumn{2}{|c|}{ Worst element for clusters 1 and 3} & $\begin{array}{l}0.08\{\mathrm{De} \\
0.53 \\
1.04 \\
2.16 \\
2.22 \\
2.76\{\mathrm{De}\end{array}$ & \\
\hline $\begin{array}{l}\mathrm{TiO}_{2} \\
\mathrm{SiO}_{2} \\
\mathrm{FeO} \\
\mathrm{K}_{2} \mathrm{O} \\
\mathrm{Al}_{2} \mathrm{O}_{3} \\
\mathrm{CaCO}_{3}\end{array}$ & Best & ment for clusters 2 and 3 & $\begin{array}{l}0.46\{\mathrm{De} \\
0.50 \\
1.00 \\
2.18 \\
2.59 \\
3.39\{\mathrm{De}\end{array}$ & \\
\hline $\begin{array}{l}\text { Clusters } \\
\text { Clusters } \\
\text { Clusters }\end{array}$ & $\begin{array}{lll}1 & \& & 2 \\
1 & \& & 3 \\
2 & \& & 3\end{array}$ & $\begin{array}{l}\text { Hardest combination to } \\
\text { Simplest combination to }\end{array}$ & $\begin{array}{l}\text { istinguish } \\
\text { distinguish }\end{array}$ & $\begin{array}{l}1.04\{\text { Means }\} \\
1.46\{\text { Means } \\
1.69\{\text { Means }\end{array}$ \\
\hline
\end{tabular}

aration between groups 1 and 2 and between groups 2 and $3, \mathrm{Al}_{2} \mathrm{O}_{3}$ and $\mathrm{CaCO}_{3}$ are the most important elements, whereas between groups 1 and $3, \mathrm{~K}_{2} \mathrm{O}$ and $\mathrm{CaCO}_{3}$ are the most important ones. This fact could be explained by the presence of different types of clay (Mascle, Lohmann, Clift, et al., 1996).

\section{CONCLUSIONS}

The reprocessing of natural gamma-ray logs improved the logging measurements obtained in the field by incorporating hole size corrections and better calibrations of $\mathrm{U}, \mathrm{Th}$, and $\mathrm{K}$. Because of a lack of XRF data at the time of this report, geochemical logs converted to oxide measurements were not compared to core trends. Only a few $\mathrm{CaCO}_{3}$ core measurements were available, and those showed good correlation with log-derived $\mathrm{CaCO}_{3}$.

The general trends of the geochemical log curves showed to be very useful in interpreting lithologic variation in Hole 959D. From the non-hierarchical cluster analysis, three different groups were defined relating to the changes in lithofacies along the interval. The general trends of $\mathrm{CaCO}_{3}$ and $\mathrm{SiO}_{2}$ values were found particularly useful in portraying increases or decreases in carbonate content. The $\mathrm{Al}_{2} \mathrm{O}_{3}, \mathrm{~K}_{2} \mathrm{O}$, and $\mathrm{FeO} \log$ curves were useful in determining presence of clay and can be in the future used in distinguishing relative amounts of clay.

\section{REFERENCES}

Archie, G.E., 1942. The electrical resistivity $\log$ as an aid in determining some reservoir characteristics. J. Pet. Technol., 5:1-8.

Bristow, J.F., Broglia, C., deMenocal, P.B., and Pratson, E.L., 1992. Data Report: Geochemical logging results from the Sea of Japan: Sites 798 and 799. In Tamaki, K., Suyehiro, K., Allan, J., McWilliams, M., et al., Proc. ODP, Sci. Results, 127/128 (Pt. 2): College Station, TX (Ocean Drilling Program), 1395-1409.

Bristow, J.F., and deMenocal, P.B., 1992. Evaluation of quality of geochemical log data in Hole 798B. In Tamaki, K., Suyehiro, K., Allan, J., McWilliams, M., et al., Proc. ODP, Sci. Results, 127/128 (Pt. 2): College Station, TX (Ocean Drilling Program), 1021-1035. 
Davis, J.C., 1986. Statistics and Data Analysis in Geology (2nd ed.): New York (Wiley).

Gonçalves, C.A., 1995. Characterisation of formation heterogeneity [Ph.D. dissert.]. Univ. of Leicester, UK.

Gonçalves, C.A., Ewert, L., and ODP Leg 159 Scientific Party, 1995. Transform margin developments: preliminary logging results from ODP Leg 159 on the Côte-D'Ivoire-Ghana Margin. Trans. 1st Latin Am. Geophys. Congr., 2:487-489.

Grau, J.A., Schweitzer, J.S., and Hertzog, R.C., 1990. Statistical uncertainties of elemental concentrations extracted from neutron-induced gammaray measurements. IEEE Trans. Nucl. Sci., 37:2175-2178.

Hertzog, R.C., Colson, J.L., Seeman, B., O'Brien, M.S., Scott, H.D., McKeon, D.C., Wraight, P.D., Grau, J.A., Ellis, D.V., Schweitzer, J.S., and Herron, M.M., 1989. Geochemical logging with spectrometry tools. SPE Form. Eval., 4:153-162.

Johnson, R.P., and Wichern, D.W., 1982. Applied Multivariate Statistical Analysis: New Jersey (Prentice-Hall).

Le Maitre, R.W., 1982. Numerical Petrology: Statistical Interpretation of Numerical Data: Amsterdam (Elsevier).

Lock, G.A., and Hoyer, W.A., 1971. Natural gamma-ray spectral logging. Log Analyst, 12:3-9.

Lovell, M.A., Harvey, P.K., and Lofts, J., 1993. Geochemical logging. 3rd Int. Congr. Brazilian Geophys. Soc., 2:964-968.
Mascle, J., Lohmann, G.P., Clift, P.D., et al., 1996. Proc. ODP, Init. Repts., 159: College Station, TX (Ocean Drilling Program).

Pratson, E.L., Broglia, C., Molinie, A., and Abrams, L., 1992. Data report: Geochemical well logs through Cenozoic and Mesozoic sediments from Sites 800, 801, and 802. In Larson, R.L., Lancelot, Y., et al., Proc. ODP, Sci. Results, 129: College Station, TX (Ocean Drilling Program), 635651.

Ruckebusch, G., 1983. A Kalman filtering approach to natural gamma ray spectroscopy in well logging. IEEE Trans. Autom. Control, AC-28:372380.

Schweitzer, J.S., Manente, R.A., and Hertzog, R.C., 1988. Elemental concentration from gamma-ray spectroscopy logs. Nucl. Geophys., 2:175-181.

Scott, H.D., and Smith, M.P., 1973. The aluminum activation log. Log Analyst, 14:3-12.

Shepherd, A., 1986. The geochemistry and evolution of Lizard Complex, Cornwall [Ph.D. dissert.]. Univ. of Nottingham, U.K.

Date of initial receipt: 21 August 1996

Date of acceptance: 23 April 1997

Ms 159SR-032 